\title{
Reproductive Characteristics, Serum Metabolites, and Oxidative Status in Female Guinea Pigs (Cavia porcellus) Fed with Ethanolic Extract of Dichrostachys glomerata Fruit
}

\author{
Nadège Motchewo Djuissi ${ }^{1}$, Ferdinand Ngoula ${ }^{1 *}$, Justin Kouamo ${ }^{2}$, Narcisse Bertin Vemo ${ }^{1}$, Mathieu Fambo Stive \\ Nono ${ }^{1}$, Aime Fulbert Lontio ${ }^{1}$, Herve Tchoffo ${ }^{1}$, and Arius Nguedia Dongmo ${ }^{1}$ \\ ${ }^{1}$ Animal Physiology and Health Research Unit, Faculty of Agronomy and Agricultural Sciences, University of Dschang, P.O. Box 188, Dschang, \\ Cameroon \\ ${ }^{2}$ School of Veterinary Medicine and Sciences, University of Ngaoundere, P.O. Box: 454, Ngaoundere, Cameroon \\ *Corresponding author's Email: fngoula@yahoo.fr; (D) ORCiD:0000-0002-6998-1957
}

\begin{abstract}
Dichrostachys glomerata (D. glomerata) is an aromatic plant which is used as a spice in cooking and Cameroonian traditional medicine to treat infertility in men. This work was designed to highlight the effects of the ethanolic extract of $D$. glomerata on oxidative status, serum metabolites and reproductive characteristics in female guinea pigs (Cavia porcellus). A total of 48 primiparous female guinea pigs, aged 4 months old with the body weight of $400 \pm$ $10 \mathrm{~g}$, were divided into four groups with two replications per group (6 guinea pigs each). During 90 days of trial, Group 1 (control group) orally received $1 \mathrm{ml} / \mathrm{kg}$ b.w. of distilled water daily, and groups 2,3 , and 4 received $D$. glomerata ethanolic extract once a day at doses of 50, 100, and $200 \mathrm{mg} / \mathrm{kg} \mathrm{b.w}$. using the same method of administration, respectively, for 90 days, including 60 days of gestation. After the first 30 days of treatment, mating was done by placing one non-treated male into cages containing six treated females. At the end of the treatment, data were collected on reproductive characteristics, serum metabolites, and oxidative stress markers. The results revealed that the ethanolic extract of $D$. glomerata induced a significant decrease in the number of post-implantation resorption and ovaries weight. Groups 3 and 4 showed a significant increase in the number of fetuses per dam and viable fetuses as well as placenta weight, compared to the control group. The serum level of progesterone significantly decreased in the group treated with $200 \mathrm{mg} / \mathrm{kg} \mathrm{D}$. Glomerata, compared to the other treated groups. The extract at $100 \mathrm{mg} / \mathrm{kg}$ body weight showed a significant increase in fetuses weight and fetuses crown-rump length, compared to the control group. Catalase activity significantly increased in the control group than $D$. glomerata treated groups. In conclusion, ethanolic extract of D. glomerata minimized reproductive stress and subsequently improved the reproductive performance of guinea pigs.
\end{abstract}

Keywords: Dichrostachys glomerata, Guinea Pig, Oxidative Stress, Reproduction, Serum Metabolites

\section{INTRODUCTION}

Guinea pigs (Cavia porcellus) cannot produce their own vitamin C (Michel et al., 2011) that acts as an antioxidant in the body under oxidative stress. Environmental factors, such as pollution, climatic change, poor quality of feed and water, as well as diseases are associated with oxidative stress that is responsible for low reproductive performance (Ngoula et al., 2020), as well as high morbidity and mortality. In addition, Deutcheu et al. (2020) observed a decrease in the fertility rate, fetal weight, viability, ovaries, and uterus weight in adult female guinea pigs exposed to oxidative stress for 90 consecutive days. In order to neutralize the environmental effects and increase animal productivity, antibiotics were massively used as feed additives. Unfortunately, antibiotic resistance was developed in pathogenic microbiota and its use was banned by the European Union and the authorities of many countries in the world (Alleman et al., 2013).

As a solution, attention has been focused on natural plant by-products rich in molecules with antioxidant properties (El-kaiaty et al., 2020). In Africa, especially in the tropical region, a larger number of plants and their extracts possess various pharmacological activities, including antioxidant, anti-inflammatory, anti-cancer, anti-microbial, and aphrodisiac properties (Raji et al., 2006). Among those tropical plants, Dichrostachys glomerata (D. glomerata), an aromatic plant from the family Fabaceae, is used worldwide as a spice and medicinal drug to cure infertility in men (Tchiégang et al., 2005). The study on the chemical components of D. glomerata fruit showed that it is rich in flavonoids, phenolic compounds, alkaloids, tannins, saponins, and terpenoids. These molecules possess numerous pharmacological activities, including cardioprotective, anti-inflammatory, antimicrobial, antioxidant, and hepatoprotective properties (Kuate et al., 2010; Kothari et al., 2010; Fankam et al., 2011). Due to these activities, D. glomerata can be used in animal production to limit the negative effects of environmental factors, and subsequently improve growth and reproductive performances. 
The aim of the current study was to investigate the effects of ethanolic extract of D. glomerata on reproductive parameters, serum metabolites, and oxidative stress markers in female guinea pigs.

\section{MATERIALS AND METHODS}

\section{Ethical approval}

Experimental protocols used in this study were approved by the ethics committee of the Department of Animal Science, Faculty of Agronomy and Agricultural Sciences, University of Dschang, Cameroon, and strictly conformed with the internationally accepted standard ethical guidelines for laboratory animal use and care described in the European Community guidelines; EEC Directive 86/609/EEC, of November 1986.

\section{Plant source and preparation of the extract}

Dry fruits of D. glomerata were bought from a local market of Bafoussam, West Region of Cameroon. They were then ground into a fine powder, conserved in an opaque flask. Following that ethanolic extract was prepared using the procedure described by Yakubu et al. (2005). Briefly, $500 \mathrm{~g}$ of D. glomerata powder was macerated in ethanol $70 \%$ for $72 \mathrm{~h}$ at room temperature. The extract was filtered with Whatman paper No. 3 and the resulting filtrate was concentrated by rotatory evaporation to remove ethanol, and further lyophilized to obtain a fine powder. The phytochemical screening of D. glomerata extract was done as described by Ramde-Tiendrebeogo et al. (2012) and Padmaja et al. (2011).

\section{Experimental animals}

The study was conducted from February to May 2019 at the Teaching and Research Farm of University of Dschang, Cameroon. A total of 48 four-month-old female guinea pigs with an average body weight of $400 \pm 10 \mathrm{~g}$ were obtained from the Teaching and Research Farm of the University of Dschang, Cameroon. Moreover, eight adult males were used only as sires and were not treated. Throughout the experimental period (90 days), drinking water and commercial complete feed Société des Provendéries du Cameroun SA containing 16\% crude protein, $2350 \mathrm{kcal} / \mathrm{kg}$ metabolizable energy, and $7 \%$ crude fiber were offered ad libitum.

\section{Experimental design}

Before starting the experiment, the animals were weighed and identified using numbered ear tags. In a completely randomized design, the female guinea pigs were divided into four equal groups (12 animals each). Each group was replicated two times with six females per replicate with comparable average body weight. The samples in the first group, which was the control group (T0) orally received $1 \mathrm{ml} / \mathrm{kg}$ bw distilled water. Groups 2, 3, and 4 received D. glomerata ethanolic extract once a day at doses of 50, 100, and $200 \mathrm{mg} / \mathrm{kg}$ b.w., respectively. All treatments were administered directly into the mouth using 5-ml syringe and daily for 90 days, including 60 days of pregnancy. After the first 30 days of treatment, mating was done by placing one non-treated male into cages containing six treated females. After 60 days of gestation, six animals were selected at random for sacrifice to investigate fetus characteristics.

\section{Organ collection and fetal parameters assessment}

At the end of the trial (day 90), six animals from each group were anesthetized using ethyl ether. The blood was collected from the jugular vein and stored at room temperature for biochemical analyses. Fetuses and organs (liver and ovaries) were carefully removed, separated from fat residues, and weighed separately using a scale of $160 \mathrm{~g}$ capacity and $10^{-3} \mathrm{~g}$ precision. The number of corpus luteum per ovary was directly naked-eyed counted. The number of pre-and postimplantation resorption was calculated by using formulas proposed by Waalkens-berendsen et al. (1998), as follows:

Pre-implantation resorptions $=$ number of corpus luteum - number of implantation site

Post implantation resorptions $=$ number of implantation sites - number of viable fetuses

The lengths of the fetus, head, and rump were measured using an electronic caliper. The number and weight of fetuses, viability, and fetal mortality rate were also measured. One part of the liver was randomly selected from each treatment, sliced and crushed in a known volume of cold $\mathrm{NaCl}, 0.9 \%$ to obtain a $15 \%$ homogenate. The resulting homogenate was centrifuged at $3000 \mathrm{rpm}$ for $30 \mathrm{~min}$ at $-0^{\circ} \mathrm{C}$, and aliquot supernatants were used for oxidative stress markers analyses.

\section{Progesterone and biochemical parameters quantification}

Serum progesterone level was determined using appropriate commercial ELISA kits (Omega diagnostics kit Scotland, United Kingdom). Toxicity markers, such as the levels of total proteins, total cholesterol, creatinine, urea, AST, and ALT, were determined using the CHRONOLAB kit (Barcelona, Spain) following the manufacturer's protocol. Oxidative stress markers, including superoxide dismutase (SOD), catalase (CAT), total peroxidises (POX) activities, 
malondialdehyde (MDA), and nitric oxide (NO) concentrations, were measured using the spectrophotometer (GENESYS 20.0, England) and according to the methods described by Misra and Fridovich. (1972), Sinha. (1972), Habbu et al. (2008), Nilsson et al. (1989), and Giustarini et al. (2008), respectively.

\section{Statistical analysis}

Statistical analyses were performed using SPSS software (IBM SPSS, USA, version 20). The difference between treatments was assessed using one-way ANOVA followed by Duncan's post hoc test. The limit of signification was 5\% and the results were expressed as mean \pm standard deviation.

\section{RESULTS}

\section{Phytochemical constituents}

Results of phytochemical screening of ethanolic extract of D. glomerata are summarized in Table 1.

\section{Effects of ethanolic extract of Dichrostachys glomerata on fetus toxicity parameters}

Fetuses toxicity parameters in guinea pigs treated with ethanolic extract of D. glomerata are shown in Table 2. The numbers of corpus luteum per dam, implantation site, fetuses per dam, viable fetuses per dam, of placenta and placenta weight insignificantly increased with the higher doses (100 and $200 \mathrm{mg} / \mathrm{kg} \mathrm{b.w.)} \mathrm{of} \mathrm{ethanolic} \mathrm{extract} \mathrm{of} \mathrm{D.} \mathrm{Glomerata,}$ compared to the control $(\mathrm{p}>0.05)$. The relative weight of ovaries was significantly decreased with the increased doses of ethanolic extract of $D$. Glomerat when compared to that of animals in the control group ( $<<0.05)$. The number of postimplantation resorptions per dam significantly increased with the smallest dose (50 mg/kg b.w.) of D. glomerata extract, compared to the control group $(\mathrm{p}<0.05)$. The number of dead fetuses per dam was comparable between female treated with $50 \mathrm{mg} / \mathrm{kg}$ b.w and those receiving distilled water $(\mathrm{p}>0.05)$ while no dead fetus and post-implantation resorption were registered at the higher doses of D. glomerata extract (100 and $200 \mathrm{mg} / \mathrm{kg} \mathrm{b.w.).} \mathrm{Regardless} \mathrm{of} \mathrm{the} \mathrm{treatment,} \mathrm{no}$ pre-implantation resorption was recorded.

\section{Effects of ethanolic extract of Dichrostachys glomeration on fetus growth characteristics}

As can be seen in Table 3, fetus weight significantly increased in the females treated with $100 \mathrm{mg} / \mathrm{kg} \mathrm{b.w.} \mathrm{of} D$. glomerata ethanolic extract, compared to animals of other treatments $(\mathrm{p}<0.05)$. Regardless of females in the control group who had a comparable head length to those received $100 \mathrm{mg} / \mathrm{kg}$ b.w. of D. glomerata ethanolic extract (p >0.05), foetus, head, and rump lengths recorded in guinea pigs administered with 100 of D. glomerata ethanolic extract significantly increased, compared to those received $50 \mathrm{mg} / \mathrm{kg} \mathrm{b.w}$. of D. glomerata ethanolic extract and control group (p $<0.05)$. However, the obtained results were similar to those received $200 \mathrm{mg} / \mathrm{kg}$ b.w. of D. glomerata ethanolic extract $(\mathrm{p}>0.05)$.

\section{Effects of Dichrostachys glomerata ethanolic extract on serum level of progesterone in guinea pig}

As shown in Figure 1, the serum level of progesterone decreased significantly in $200 \mathrm{mg} / \mathrm{kg}$ b.w. of D. glomerata treated group in comparison with the control and other treated groups $(\mathrm{p}<0.05)$. Nevertheless, the serum level in progesterone recorded in the control group was comparable to those in D. glomerata treated animals at doses of 50 and $100 \mathrm{mg} / \mathrm{kg}$ b.w. (p > 0.05).

\section{Effects of Dichrostachys glomerata ethanolic extract on biochemical parameters in female guinea pigs}

As shown in Table 4, D. glomerata ethanolic extract did not significantly affect serum content in total proteins, albumin, globulins, ALT, and creatinine concentrations, compared to the control ( $p>0.05)$. In guinea pigs treated with ethanolic extract of D. glomerata, the serum level of total cholesterol and AST significantly increased with the increasing doses of extract $(\mathrm{p}<0.05)$. Compared to the control group the serum level of total cholesterol significantly increased only in females treated with $200 \mathrm{mg} / \mathrm{kg}$ b.w. of D. glomerata ethanolic extract $(\mathrm{p}<0.05)$ and AST was comparable among all treatments $(\mathrm{p}>0.05)$. The D. glomerata ethanolic extract increased the serum level of urea but, this effect was significant only at $200 \mathrm{mg} / \mathrm{kg}$ b.w., compared to the control $(\mathrm{p}<0.05)$.

\section{Effects of Dichrostachys glomerata ethanolic extract on oxidative status in female guinea pig}

The results presented in Table 5 indicated that D. glomerata ethanolic extract doses did not significantly affect SOD, total peroxidase activities, MDA, and NO concentrations ( $p>0.05$ ). Although statistically comparable, the level of MDA and NO decreased with D. glomerata at doses of 100 and $200 \mathrm{mg} / \mathrm{kg} \mathrm{b.w.,} \mathrm{compared} \mathrm{to} \mathrm{control.} \mathrm{The} \mathrm{activity} \mathrm{of}$ catalase was comparable in D. glomerata treated guinea pigs, but significantly lower, compared to the value recorded in control animals $(\mathrm{p}<0.05)$. 
Table 1. Phytochemical constituents of Dichrostachys glomerata ethanolic extract.

\begin{tabular}{lc}
\hline Constituents & + \\
\hline Flavonoids & + \\
Alkaloids & + \\
Phenols & + \\
Tannins & + \\
Triterpenes & - \\
Steroids & + \\
Saponins & +
\end{tabular}

Table 2. Ovary weight and fetus index in female guinea pigs treated with ethanolic extract of Dichrostachys glomerata

\begin{tabular}{lccccc}
\hline \multirow{2}{*}{ Foetotoxicity characteristic } & \multicolumn{2}{c}{ Doses of Dichrostachys glomerata extract (mg/kg b.w.) } & p-value \\
\cline { 2 - 5 } & $\mathbf{0}(\mathbf{n}=\mathbf{6})$ & $\mathbf{5 0}(\mathbf{n}=\mathbf{6})$ & $\mathbf{1 0 0}(\mathbf{n}=\mathbf{6})$ & $\mathbf{2 0 0}(\mathbf{n}=\mathbf{6})$ & \\
\hline Number of corpus luteum/dam & $2.33 \pm 0.52$ & $2.67 \pm 0.52$ & $2.50 \pm 0.55$ & $2.50 \pm 0.55$ & 0.684 \\
\hline Relative weight of both ovaries (g/100 g b.w.) & $0.009 \pm 0.008^{\mathrm{a}}$ & $0.008 \pm 0.001^{\mathrm{ab}}$ & $0.007 \pm 0.001^{\mathrm{b}}$ & $0.007 \pm 0.002^{\mathrm{b}}$ & 0.048 \\
\hline Number of implantation sites/animal & $2.33 \pm 0.52^{\mathrm{b}}$ & $2.67 \pm 0.52^{\mathrm{a}}$ & $2.50 \pm 0.55^{\mathrm{ab}}$ & $2.50 \pm 0.55^{\mathrm{ab}}$ & 0.048 \\
\hline Number of pre-implantation resorptions/animal & $0.00 \pm 0.00$ & $0.00 \pm 0.00$ & $0.00 \pm 0.00$ & $0.00 \pm 0.00$ & 1.000 \\
\hline Number of post-implantation resorptions/animal & $0.17 \pm 0.05^{\mathrm{b}}$ & $0.33 \pm 0.12^{\mathrm{a}}$ & $0.00 \pm 0.00$ & $0.00 \pm 0.00$ & 0.049 \\
\hline Number of fetus/dam & $2.33 \pm 0.52^{\mathrm{ab}}$ & $2.33 \pm 0.52^{\mathrm{ab}}$ & $2.50 \pm 0.55^{\mathrm{a}}$ & $2.50 \pm 0.55^{\mathrm{a}}$ & 0.046 \\
\hline Number of viable fetuses/ dam & $2.17 \pm 0.41^{\mathrm{ab}}$ & $2.00 \pm 0.52^{\mathrm{b}}$ & $2.50 \pm 0.55^{\mathrm{a}}$ & $2.50 \pm 0.55^{\mathrm{a}}$ & 0.049 \\
\hline Number of dead fetuses/ dam & $0.17 \pm 0.05$ & $0.33 \pm 0.12$ & $0.00 \pm 0.00$ & $0.00 \pm 0.00$ & 0.596 \\
\hline Number of placenta/dam & $2.33 \pm 0.52$ & $2.33 \pm 0.52$ & $2.50 \pm 0.55$ & $2.50 \pm 0.55$ & 0.083 \\
\hline weight of placenta $(\mathrm{g})$ & $4.25 \pm 0.71^{\mathrm{ab}}$ & $3.63 \pm 0.74^{\mathrm{b}}$ & $4.49 \pm 0.45^{\mathrm{a}}$ & $4.51 \pm 0.49^{\mathrm{a}}$ & 0.025 \\
\hline
\end{tabular}

$\stackrel{\mathrm{a}, \mathrm{b}}{\mathrm{a}}$ In the same row, means with different letters are significantly different $(\mathrm{p}<0.05)$. n: Number of animals

Table 3. Effects of ethanolic extract of Dichrostachys glomerata on fetus growth characteristics

\begin{tabular}{lccccc}
\hline \multirow{2}{*}{ Fetuses mensuration } & \multicolumn{2}{c}{ Doses of Dichrostachys glomerata extract $(\mathbf{m g} / \mathbf{k g}$ b.w) } & \multicolumn{2}{c}{ p value } \\
\cline { 2 - 6 } & $\mathbf{0}(\mathbf{n}=\mathbf{6})$ & $\mathbf{5 0}(\mathbf{n}=\mathbf{6})$ & $\mathbf{1 0 0}(\mathbf{n}=\mathbf{6})$ & $\mathbf{2 0 0}(\mathbf{n}=\mathbf{6})$ & \\
\hline Fetus weight $(\mathrm{g})$ & $41.18 \pm 7.89^{\mathrm{cb}}$ & $39.69 \pm 4.45^{\mathrm{c}}$ & $55.64 \pm 6.09^{\mathrm{a}}$ & $47.75 \pm 5.61^{\mathrm{b}}$ & 0.001 \\
\hline Fetus length $(\mathrm{mm})$ & $8.58 \pm 0.94^{\mathrm{b}}$ & $8.84 \pm 1.13^{\mathrm{b}}$ & $10.06 \pm 1.18^{\mathrm{a}}$ & $9.39 \pm 0.52^{\mathrm{ab}}$ & 0.000 \\
\hline Head length $(\mathrm{mm})$ & $3.28 \pm 0.26^{\mathrm{ab}}$ & $3.13 \pm 0.51^{\mathrm{b}}$ & $3.58 \pm 0.41^{\mathrm{a}}$ & $3.44 \pm 0.44^{\mathrm{ab}}$ & 0.047 \\
\hline Rump length $(\mathrm{mm})$ & $1.97 \pm 0.29^{\mathrm{b}}$ & $2.09 \pm 0.35^{\mathrm{b}}$ & $2.54 \pm 0.41^{\mathrm{a}}$ & $2.53 \pm 0.44^{\mathrm{a}}$ & 0.001 \\
\hline
\end{tabular}

$\overline{\mathrm{a}, \mathrm{b}, \mathrm{c}}$ : In the same row, means with different letters are significantly different $(\mathrm{p}<0.05)$. n: number of animals.

Table 4. Effects of ethanolic extract of Dichrostachys glomerata on biochemical parameters in female guinea pig

\begin{tabular}{|c|c|c|c|c|c|}
\hline \multirow{2}{*}{ Biochemical parameters } & \multicolumn{4}{|c|}{ Doses of Dichrostachys glomerata extract (mg/kg b.w) } & \multirow[t]{2}{*}{$p$ value } \\
\hline & $\mathbf{0}(\mathbf{n}=6)$ & $50(n=6)$ & $100(n=6)$ & $200(n=6)$ & \\
\hline Serum total proteins $(\mathrm{g} / \mathrm{dl})$ & $6.74 \pm 1.10$ & $5.90 \pm 0.61$ & $6.69 \pm 0.81$ & $6.83 \pm 0.56$ & 0.363 \\
\hline Albumin $(g / d l)$ & $3.33 \pm 0.61$ & $2.79 \pm 0.29$ & $2.74 \pm 0.64$ & $3.00 \pm 0.76$ & 0.518 \\
\hline Globulins (g/dl) & $3.41 \pm 0.78$ & $3.11 \pm 0.57$ & $3.95 \pm 0.76$ & $3.83 \pm 0.46$ & 0.293 \\
\hline Total cholesterol (mg/dl) & $48.83 \pm 9.1^{\mathrm{bc}}$ & $38.76 \pm 7.37^{\mathrm{c}}$ & $54.38 \pm 4.0^{\mathrm{b}}$ & $65.70 \pm 6.14^{\mathrm{a}}$ & 0.003 \\
\hline ALT (Ul) & $55.37 \pm 9.08$ & $42.00 \pm 7.58$ & $46.38 \pm 6.86$ & $49.06 \pm 9.32$ & 0.169 \\
\hline AST (Ul) & $51.19 \pm 6.96^{\mathrm{ab}}$ & $44.63 \pm 5.80^{\mathrm{b}}$ & $59.00 \pm 7.73^{\mathrm{a}}$ & $57.44 \pm 9.15^{\mathrm{a}}$ & 0.041 \\
\hline Creatinine (mg/dl) & $1.48 \pm 0.27$ & $1.18 \pm 0.25$ & $1.28 \pm 0.29$ & $1.24 \pm 0.25$ & 0.360 \\
\hline Urea (mg/dl) & $42.24 \pm 7.52^{\mathrm{b}}$ & $39.58 \pm 6.54^{\mathrm{b}}$ & $48.95 \pm 4.35^{\mathrm{ab}}$ & $58.13 \pm 6.91^{\mathrm{a}}$ & 0.006 \\
\hline \multicolumn{6}{|c|}{$\begin{array}{l}\mathrm{a}, \mathrm{b}, \mathrm{c} \text { : In the same row, means with different letters are significantly different }(\mathrm{p}<0.05) \text {. n: Number of animals. ALT: Alanine transaminase; AS } \\
\text { Aspartate transaminase }\end{array}$} \\
\hline \multirow{2}{*}{ Oxidative stress markers } & \multicolumn{4}{|c|}{ Doses of Dichrostachys glomerata extract (mg/kg b.w) } & \multirow{2}{*}{ p value } \\
\hline & $0(n=6)$ & $50(n=6)$ & $100(n=6)$ & $200(n=6)$ & \\
\hline $\mathrm{SOD}(\mathrm{U} / \mathrm{min} / \mathrm{g}$ of hepatic proteins) & $0.35 \pm 0.07$ & $0.39 \pm 0.05$ & $0.43 \pm 0.05$ & $0.39 \pm 0.09$ & 0.334 \\
\hline $\mathrm{CAT}(\mu \mathrm{M} / \mathrm{min} / \mathrm{g}$ of hepatic proteins) & $1.67 \pm 0.26^{\mathrm{a}}$ & $1.28 \pm 0.10^{\mathrm{b}}$ & $1.19 \pm 0.14^{\mathrm{b}}$ & $1.04 \pm 0.19^{\mathrm{b}}$ & 0.000 \\
\hline Total peroxidase (mM/min/g of hepatic proteins) & $30.58 \pm 7.38$ & $28.33 \pm 4.69$ & $24.28 \pm 2.17$ & $29.88 \pm 2.51$ & 0.267 \\
\hline MDA ( $\mu \mathrm{M} / \mathrm{g}$ of liver $)$ & $2.55 \pm 0.45$ & $2.26 \pm 0.41$ & $2.11 \pm 0.34$ & $2.09 \pm 0.29$ & 0.259 \\
\hline $\mathrm{NO}(\mu \mathrm{M} / \mathrm{g}$ of liver $)$ & $21.00 \pm 3.97$ & $21.23 \pm 4.50$ & $17.47 \pm 2.35$ & $17.49 \pm 3.62$ & 0.334 \\
\hline
\end{tabular}

$\overline{\mathrm{a}, \mathrm{b}}:$ In the same row, means with different letters are significantly different $(\mathrm{p}<0.05)$. n: Number of animals. 


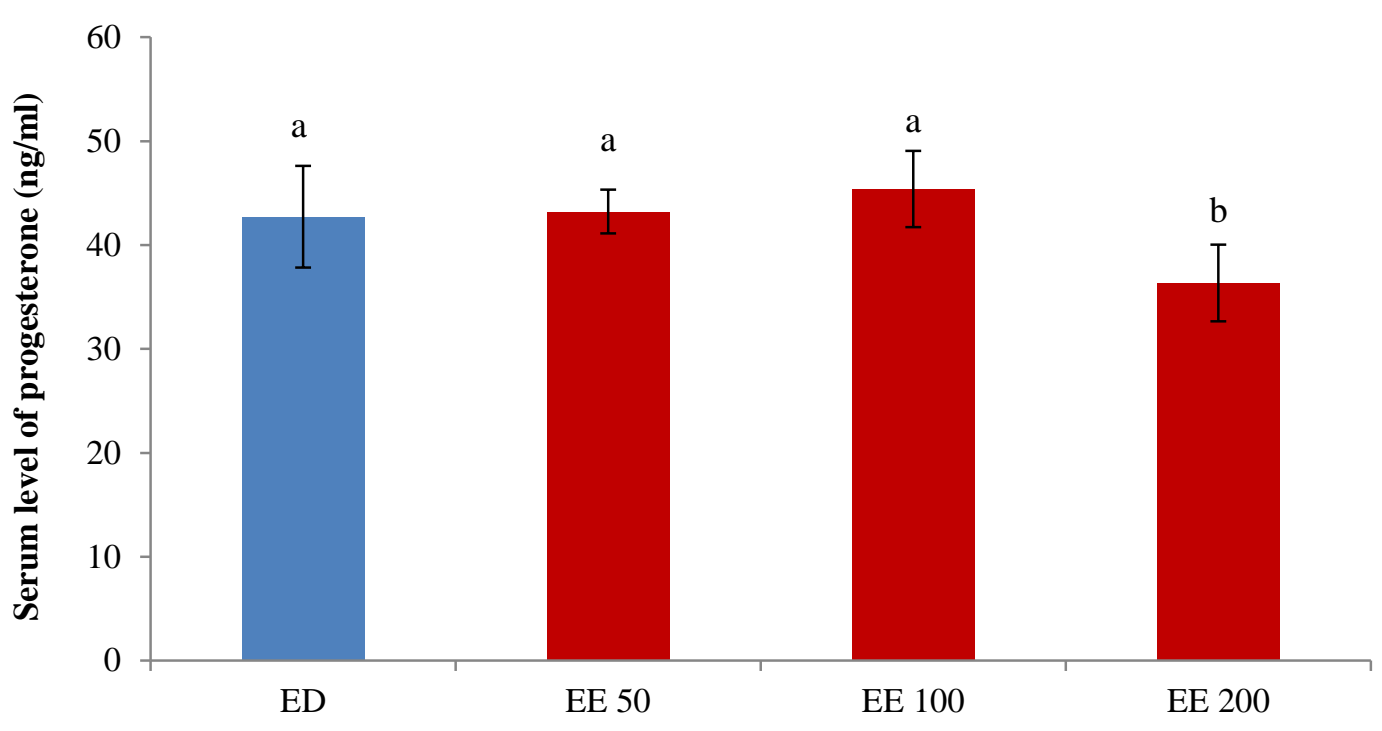

Doses of ethanolic extrect of Dichrostachys glomerata (mg/kg b.w.)

Figure 1. Effects of ethanolic extract of Dichrostachys glomerata on serum level of progesterone in guinea pigs treated with different doses. ${ }^{\mathrm{a}, \mathrm{b}}$ : Means with different letters are significantly different $(\mathrm{p}<0.05)$. ED: Distill water. EE 50, EE 100, and EE 200: 50, 100, $200 \mathrm{mg} / \mathrm{kg}$ b.w of D. glomerata ethanolic extract, respectively.

\section{DISCUSSION}

The chemical screening of D. glomerata ethanolic extract carried out in the present study revealed the presence of phenols, tannins, triterpenes, saponins, alkaloids, and flavonoids. These molecules have diverse activities (antioxidants, antibacterial, anti-inflammatory, antiseptic, antiparasitic, and immunomodulatory properties) and can improve animal reproductive characteristics (Kuate et al., 2010; Tchoffo et al., 2019).

Oral administration of D. glomerata ethanolic fruits extract at doses of 100 and $200 \mathrm{mg} / \mathrm{kg} \mathrm{b}$.w. for 90 consecutive days to female guinea pig increased the number of implantation sites, fetuses per dam, and viable fetuses. These results corroborated those obtained by Watcho et al. (2009) who observed a significant increase in the number of implantation sites and the number of litter sizes per dam in rats treated during 7 consecutive days with $100 \mathrm{mg} / \mathrm{kg} \mathrm{b}$.w. of aqueous extract of Ficus asperifolia. These results are related to the bioactive molecules present in D. glomerata fruit which can induce a favorable milieu for zygote implantation and development. According to Grzanna et al. (2005) phenolic and alkaloids compounds present in D. glomerata have reputed to reinforce the endogenic antioxidant system of animals and protect embryonic tissue against reactive oxidative stress attacks. This effect subsequently enhances zygote implantation, fertility rate, and the survival rate of animals after birth.

Progesterone is required in all mammals to support the survival and development of the embryo/fetuses and attached membranes (Spencer and Bazer, 2002). It is produced by the ovaries and placenta and helps to prepare the body for conception and pregnancy (Montaserti et al., 2007). The results of the present study showed an increased level of progesterone in female groups treated with 50 and $100 \mathrm{mg} / \mathrm{kg}$ b.w. of ethanolic extract of D. glomerata. These results agreed with those obtained by Bafor et al. (2015) in mice received orally Alchornea laxiflora methanol leaf extract at $1000 \mathrm{mg} / \mathrm{kg}$ for 6 consecutive days and Yakubu et al. (2008) in female rats treated with Cnidoscolous aconitifolius for 7 consecutive days. This observation can be attributed to some bioactive molecules, such as alkaloids and phenols, present in $D$. glomerata extract that protect corpus luteum and placenta from reactive oxygen species attacks, and subsequently favor the growth and function of the cells.

In the present study, all fetuses' growth characteristics (fetus weight, fetus, head, and rump length) significantly increased in animals treated with $100 \mathrm{mg} / \mathrm{kg}$ of $D$. glomerata ethanolic extract, compared to the control group. This effect can be due to the best plasmatic availability and mobilization of nutriment for fetuses' growth during gestation. This hypothesis is supported by the increase in serum level of total proteins, albumin, globulins, and total cholesterol with a high dose of $D$. glomerata extract. These results are in agreement with those obtained by Ebile et al. (2018), who observed an increased level of total proteins, albumin, globulins, and total cholesterol in quails treated with $5 \mathrm{~g}$ of $D$. glomerata powder incorporated in drinking water.

The decreased level of ALT observed in the present study agreed with those recorded by Kothari et al. (2014) in rats treated orally with $1000 \mathrm{mg} / \mathrm{kg}$ of D. glomerata fruit ethanolic extract for 90 days. This observation can be directly related to the hepatoprotective effects of ethanolic extract of D. glomerata. However, the increased level of AST can be due to the fact that AST is produced by many other organs, such as kidney, heart, and muscle, apart from the liver. 
Additionally, the significantly increased level of urea recorded in the current study was positively corralled with higher kidney metabolism and consequently responsible for AST increased level. These results disagreed with those observed by Kothari et al. (2014) and Ebile et al. (2018). Urea and creatinine are used to evaluate the level of protein metabolism and kidney function. The present study indicated an increased level of urea and a decreased level of creatinine which was in contrast with findings of Kothari et al. (2014) and Ebile et al. (2018). The obtained results of the present study resulted from the increased level of protein metabolism which could make some changes in kidney cell function.

Pregnancy is a state characterized by an increase in reactive oxygen species (ROS) production, particularly placental metabolic and steroidogenic activities involved in the increase of oxygen consumption by the fetoplacental unit (Myatt and Cui, 2004). In the current study, there was an increase in SOD as the first antioxidant enzyme to neutralize the ROS (Agarwal et al., 2005). Meanwhile, the decreased level of MDA and NO levels can express the cell-protective effects of $D$. glomerata extract. These results agree with those obtained by Kuate et al. (2010) who analyzed the in vitro antioxidant activity of $D$. glomerata extracts. In fact, the phytochemical screening of $D$. glomerata extract revealed the presence of alkaloids, saponins, phenolics, tannins, flavonoids, and triterpenes which have been recognized to have antioxidant properties (Sen et al., 2010).

\section{CONCLUSION}

The present study demonstrated the oral administration of D. glomerata ethanolic extract at doses of $100 \mathrm{and} 200 \mathrm{mg} / \mathrm{kg}$ b.w. positively influenced the fetuses growth characteristics. Due to the diverse bioactive molecules with antioxidant properties, D. glomerata ethanolic extract protects the animal cells, including reproductive cells from reactive oxygen species attacks which subsequently improves animal reproductive performances.

\section{DECLARATIONS}

\section{Acknowledgments}

We express our heartfelt thanks to the staff members of the Department of Animals Production, and Laboratory of Physiology and Animals Health, University of Dschang, Cameroon, for their boundless and selfless help.

\section{Authors' contributions}

Ngoula Ferdinand and Kouamo Justin supervised and designed the project, cross-checked the draft of the manuscript, and finally approved it for submission. Djuissi Motchewo Nadège and Ngoula Ferdinand designed the project, conducted the experiment, analyzed data, and wrote the first draft of the manuscript. Nono Fambo Stive Mathieu and Lontio Fulbert Aimé assisted in the conduction of the experiment and data collection. Vemo Bertin Narcisse, Tchoffo hervé, and Dongmo Nguedia Arius conducted laboratory analyses of the experiment. All the authors approved the final draft of the manuscript for submission.

\section{Competing interests}

Authors have declared that no competing interests exist.

\section{REFERENCES}

Agarwal A, Gupta S, and Sharma R (2005). Oxidative stress and its implications in female infertility - a clinician's perspective. Reproductive BioMedicine Online, 11(5): 641-650. DOI: https://doi.org/.10.1016/s1472-6483(10)6117.

Alleman F, Gabriel I, Dufourcq V, Perrin F, and Gabarrou JF (2013). Essential oils in poultry feeding. 1. Growth performances and regulation aspects. Productions Animals, 26(1): 3-12. DOI: https://www.inra.fr/productions-animales.

Bafor EE, Eyohan ES, Omoruyi O, Elvis-Offial U, Ayinde B, Eze GI, Okosun IV, Obarisiagbon AP, Igbinuwen O, and Braimoh KP (2015). Preliminary endocrinological, histological and haematological investigation of Alchornea laxiflora (Euphorbiaceae) leal extract effects on the ovary, uterus and cervix of mouse models. Journal of Science and Practice of Pharmacy, 2(1): 55-63. Available at: https://www.jsppharm.org.

Deutcheu NS, Ngoula F, Tchoffo H, Mabou NJL, Vemo BN, and Tchoumboue J (2020). Protective effect of ethanolic extract of spirulina platensis on reproductive characteristic and biochemical profile in female guinea pig (Cavia porcellus) exposed to lead acetate. Journal of Experimental Agriculture International, 42(2): 37-46. DOI: https://www.doi.org/10.9734/JEAI/2020/v42i230468.

Ebile DA, Kana JR, Pimagha MHJ, Edie NLW, Nguefack DG, Ngouana TR, and Fonteh AF (2018). Effects of Dichrostachys Glomerata feeding regimes on growth performance, gut microbiota and haemato-biochemical profile of Japanese quails. Journal of Animal Research and Nutrition, 3(2): Article number: 5. DOI: https://www.doi.org/10.21767/2572-5459.100049.

El-kaiaty AM, El-Moghazy GM, El-Manylawi MAF, and Abdel-Mageed MGY (2020). Impact of thyme oil and Lactobacillus acidophilus as natural growth promoters on performance, Blood Parameters and Immune Status in Growing Rabbits. World's Veterinary Journal, 10(1): 1-11. DOI: https://www.dx.doi.org/10.36380/scil.2020.wvj1.

Fankam AG, Kuete V, Voukeng IK, Kuate JR, and Pages JM (2011). Antibacterial activities of selected Cameroonian spices and their synergistic effects with antibiotics against multidrug-resistant phenotypes. BMC Complement Alternative Medicine, 11(1): Article number: 104. DOI: https://www.doi.org/10.1186/1472-6882-11-104 
Giustarini D, Rossi R, Milzani A, and Dalle-Donne I (2008). Nitrite and nitrate measurement by Griess reagent in human plasma: evaluation of interferences and standardization. Methods Enzymology, 440(7): 361-380. DOI: https://www.doi.org/10.1016/S0076-6879(07)00823-3.

Grzanna R, Lindmark L and Frondoza CG (2005). Ginger an herbal medicinal product with broad anti-inflammatory actions. Journal of Medicinal Food, 8(2): 125-132. DOI: https://www.doi.org/10.1089/jmf.2005.8.125.

Habbu PV, Shastry RA, Mahadevan KM, Hanumanthachar J, and Das SK (2008). Hepatoprotective and antioxidant effects of Argyreia speciosa in rats. African Journal of Traditional Complementary and Alternative Medicine, 5(2): 158-164. DOI: https://www.doi.org/10.4314/ajtcam.v5i2.31268.

Kothari SC, Shivarudraiah P, Venkataramaiah SB, Gavara S, Arumugam SN, and Soni MG (2014). Toxicologic evaluation of Dichrostachys glomerata extract: Subchronic study in rats and genotoxicity tests. Food and Chemical Toxicology, 69: 120-131. Available at: DOI: https://www.doi.org/10.1016/j.fct.2014.03.045.

Kuate D, Etoundi BCO, Soukontoua YB, Ngondi JL, and Oben JE (2010). Antioxidant characteristics of Dichrostachys glomerata spice extracts Caracteristicas antioxidantes de los extractos de la especia Dichrostachys glomerata. CyTA - Journal of Food, 8(1): 23-37. DOI: https://www.doi.org/10.1080/19476330903129126

Michel CL, Chastel O, and Bonnet X (2011). Ambient temperature and influence cortisol levels in female guinea pigs and entail long-term effects on the stress response of their offspring. Gen Comp Endocrinol, 171: 275-282. DOI: https://doi.org/10.1016/j.ygcen.2011.02.007.

Misra HP, and FridovichI (1972). The generation of superoxide radical during the autoxidation of hemoglobin. The Journal of Biological Chemistry, 247(21): 6960-6962. Available at http://www.jbc.org.content/247/21/6960.

Montaserti A, Pourheydar M, Khazaei M, and Ghorbani R (2007). Ant-fertility effects of physalis alkekengi alcoholic extract in female rat. Iranian Journal of Reproductive Medicine, 5(1): 13-16. Available at: https://journals.ssu.ac.ir/ijrmnew/article-1-62-en.pdf.

Myatt L. and Cui X (2004). Oxidative stress in placenta. Histochemical. Cell Biology, 122(4): 369-382. DOI: https://www.doi.org/10.1007//s00418$\underline{004-0677-X .}$

Ngoula F, Lontio FA, Tchoffo H, Tsague FPM, Djeunang RM, Vemo BN, Moffo F, and Motchewo ND (2020). Heat induces oxidative stress: reproductive organ weights and serum metabolite profile, testes structure, and function impairment in male cavy (Cavia porcellus). Frontiers Veterinary Science, 7: Article number: 37. DOI: https://www.doi.org/10.3389/fvets.2020.00037.

Nilsson UA, Olsson LI, and Carlin G (1989). Inhibition of lipid peroxidation by spin labels. Journal of Biological Chemistry, 264(19): 11131-11135. Available at: https://www.jbc.org/11131.full.pdf.

Padmaja M, Sravanthi M, and Hemalatha KPJ (2011). Evaluation of antioxidant activity of two Indian Medical plants. Journal of Phytology, 3(3): 8691. Corpus ID: 55451964.cc.

Raji Y, Fadare OO, Adisa RA, and Salami SA (2006). Comprehensive assessment of the effect of Sphenocentrum jollyanum root extract on male reproductive activity in albino rats. Reproductive Medecine Biology, 23(4): 283-292. DOI:_https://www.doi.org/10.1111/j.1447$\underline{0578.2006 .00154 .}$

Ramde-Tendrebeogo A, Tibiri A, Hilou A, Lompo M, Millogo-Kone H, Nacoulma OG, and Guissou IP (2012). Antioxidant and antibacterial activities of phenolic compounds from Ficus sur Forssk. and ficus sycomocus L. (Moraceae): potential for sickle cell disease treatment in Burkina Faso. International Journal of Biological and Chemical Sciences, 6(1): 328-336. DOI: https://www.doi.org/10.4314/ijbcs.v6i1.29.

Sen S, Chakraborty R, Sridhar C, Reddy YSR, and Biplab (2010). Free radicals, antioxidants, diseases and phytomedicines: current status and future prospect. International Journal of Pharmaceutical Sciences Review and Research, 3(1): Article number: 10. Available at: https://www.globalresearchonline.net .

Sinha AK (1972). Colorimetric assay of catalase. Analytical Biochemistry, 47(2): 389-394. DOI: https://www.doi.org:10.1016/0003(72)90132-7.

Spencer TE, and Bazer FW (2002). Biology of progesterone action during pregnancy recognition and maintenance of pregnancy. Frontiers in Bioscience, 7: 1879-1898. DOI: https://www.doi.org/10.2741/spencer.

Tchiégang C, and Mbougueng PD (2005). Chemical composition of spices used in the cooking of Nah poh and Nkui of western Cameroon. Tropicultura, 23(4): 193-200. Available at: https://journalofethnicfoods.biomedcentral.com/articles/10.1186/s42779-019-0030-6.

Tchoffo H, Kana JR, Ngoula F, Ngoumtsop VH, Ngouozeu MM, Tadondjou CDA, and Folack TLV (2019). Effects of ginger (Zingiber officinale, Roscoe) essential oil on growth and laying performances, serum metabolites, and egg yolk antioxidant and cholesterol status in laying Japanese quail. Journal of Veterinary Medicine, Article ID 7857504. DOI: https://www.doi.org/10.1155/2019/7857504.

Watcho P, Ngadjuia E, Alangob NEP, Benoîta NT, and Kamanyi A (2009). Reproductive effects of Ficus asperifolia (Moraceae) in female rats. African Health Sciences, 9(1): 49-53. Available at: https://pubmed.ncbi.nlm.nih.gov/20842243/.

Waalkens-berendsen DH, Verhagen JJ, and Bar A (1998). Embryotoxity and teratogenicity study with gamma cyclodextrin in rats. Regulatory Toxicology and Pharmacology, 27: 166-177. DOI: https://www.doi.org/10.1006/rtph.1998.1221.

Yakubu MT, Akanji MA, and Oladiji AT (2005). Aphrodisiac potentials of the aqueous extract of Fadogia agrestis (Schweinf. Ex Hiern) stem in male

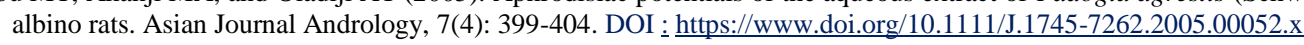

Yakubu MT, Akanji MA, Oladiji AT, Olatinwo AWO, Adesokan AA, Yakubu MO, Owoyele BV, Sunmonu TO, and Ajao MS (2008). Effect of Cnidoscolous aconitifolius (Miller) I.M. Johnston leaf extract on reproductive hormones of female rats. Iranian Journal of Reproductive Medicine, 6(3): 149-155. Available at: https://journals.ssu.ac.ir/ijrmnew/article-1-115-en.pdf. 